\title{
Legislative Aspects of Environmental Inquiries Pertaining to Problems of Families Related to Social Support
}

\author{
Ewa Jurczyk-Romanowska \\ Ph.D.University of Wroclaw
}

\begin{abstract}
The paper presents the legal conditions created by the state dedicated to people in difficult financial situation. In particular the analysis focuses on the guidelines of the Act of March 12, 2004 on social support and the Ordinance of the Minister of Family, Labour, and Social Policy of August 26, 2016 on environmental inquiries in the family. According to the aforementioned act "environmental inquiry in the family is conducted with persons and families who benefit from or have applied for social support in order to establish their personal, family, financial, and material situation" (art. $107 \mathrm{sec} .1$ ). The following problems are discussed in the present paper: the guidelines of conducting environmental inquiries in the family, the subjects eligible to carry out the inquiries, and the methods of documenting the interviews. The problems pertaining to the conditions of being granted financial help by the government are changing dynamically in Poland, while the institutions that provide the support ought to be stable and guarantee the reception of support if the necessary conditions are met.
\end{abstract}

Keywords: environmental inquiry in the family, social support, system of support for families, poverty.

\section{The system of social support in Poland}

One of the most important institutions of state social policies is social support, whose aim is to make it possible for individuals and families to overcome difficult life situations which they cannot themselves overcome with the use of their own resources, opportunities, or legitimations (Act of March 12, 2004 on social support, art. 2.1). The Minister of Family, Labour, and Social Policy, a chief body in government administration, is responsible for the organisation of social support. Currently in Poland it is Elżbieta Rafalska (Ministry of Family, Labour and Social Policy, 2016a). On the level of voivodships social support is organised by the voivods, and as part of the units of territorial government also the voivodship marshals, as well as starosts on the poviate level and voits, mayors (city presidents) on the level of boroughs. When carrying out their duties pertaining to social support these government bodies cooperate with non-governmental organisations, the Roman Catholic Church, other churches and religious associations, as well as individuals and legal entities (Act of March 12, 2004 on social support, art. 2.2).

The aim of social support is to help individuals and families in fulfilling their basic needs and achieving a living standard securing human dignity. The goal of social support is the prevention of difficult life situations and undertaking actions aimed to help individuals and families live independently and to integrate with the communities (Act of March 12, 2004 on social support art. 3). In Poland social support is provided on the basis of two criteria. The first criterion is income (commonly called the threshold of entrance to the system of social support) which is a formal premise; the second criterion is social risks that threaten an individual or a family - the risks are listed in the act on social support (factual premise). Both the criteria ought to be met simultaneously (Broda-Wysocki, n.d.).

The circle of persons eligible for social support is defined by formal premises. Firstly, the act enumerates the persons with Polish citizenship, with registered residence and currently residing in Poland (Act of March 12, 2004 on social support, art. 5). What is more, social support funds can be received by foreigners with registered residence and currently residing in Poland on the basis of residence permits (permanent or temporary) as well as residence permits based on humanitarian premises or tolerated residence permits granted to refugees and migrants. These rights are also granted to citizens of the European Union, the countries of the European Free Trade Association, the Swiss Confederation and their families residing in the Republic of Poland (Act of March 12, 2004 on social support art. 5). Furthermore, according to the act the subjects applying for social support need to meet the following income criteria: 
single household income - 634 PLN (ca. € 1441),

income per family member - 514 PLN (ca. € 117),

family income - the amount depends on the number of family members and does not exceed the limit for income per family member.

The act on social support enumerates examples of situations that constitute a factual criterion to apply for social support. These include social risks such as: (1) poverty, (2) orphanhood, (3) homelessness, (4) unemployment, (5), disability, (6) enduring or severe illness, (7) domestic violence, (8) the necessity to protect the victims of human trafficking, (9) the necessity to protect motherhood and numerous families, (10) helplessness in parenthood and running the household (particularly in single-parent and numerous families), (11) difficulties with the integration of foreigners who have been granted asylum in Poland, as well as (12) alcoholism and drug addiction, (13) accidents and crises, and (14) natural and ecological disasters (Act of March 12, 2004 on social support, art. 7). The enumeration is open, which means that individuals and families in situations similar but not listed in the act can also apply for social support from the state.

The persons who qualify according to both formal and factual criteria can receive support from the state in the form of (1) benefits, (2) community work, (3) conducting and developing necessary social infrastructure, (4) analysis and evaluation of the phenomena generating the need for social support, (5) realisation of the aims arising from a recognition of social needs, (6) developing new forms of social support and self help within the boundaries of the recognised needs (Act of March 12 , 2004 on social support, art. 15). The support is aimed at:

supporting individuals and families in difficult life situations, if possible, allowing them to live independently in conditions securing human dignity,

providing income on the level of social intervention - for individuals with no income or low income, in post-productive age, and the handicapped,

providing income to the level of social intervention to persons and families with low income who demand temporary support,

providing professional help to families that fall victim to social pathology including domestic violence,

integrating the socially excluded into their communities,

creating a network of social services adequate to the needs (Ministry of Family, Labour and Social Policy, 2017).

The social support system provides two types of benefits: monetary and non-monetary. The first type includes permanent and temporary benefits. Monetary benefits include also designated benefits and special designated benefits, benefits and loans to become financially independent, benefits for foster families, the benefits to become independent and continue education, benefits for livelihood and the expenditures connected with learning Polish for foreigners. The non-monetary benefits typically take the form of social services for those afflicted by social risks. The most important of them is community work (Broda-Wysocki, n.d.).

The social support benefits are granted when applied for by: (1) the individual to receive them, (2) their legal representative, (3) a third party, as agreed by the interested person or their legal representative. Social benefits may also be granted by the administration. An individual or a family can apply to a social support centre in their place of residence (the centres are located in every borough) (Ministry of Family, Labour and Social Policy, 2017).

\section{Environmental inquiry in the family}

The decisions on the basis of which the support is granted or not call for the conducting of an environmental inquiry. The legal basis is art. 107 of the Act on social support which, in sect. 1 states: "Environmental inquiry in the family is conducted with persons and families who benefit from or have applied for social support in order to establish their personal, family, financial, and material situation" (Act of March 12, 2004 on social support, art. 107.1). It is a particular type of evidence, obligatory to be carried out in all the cases connected with social support except for the granting of a credit ticket and providing help for foreigners-victims of human trafficking (Act of March 12, 2004 on social support, art. 106.4). The Chief

${ }^{1}$ Calculated on the basis of the exchange rate of 22.12.2016: 1 EUR=4.4 PLN. 
Administrative Court in its ruling of May 7, 2002 emphasises the role of environmental inquiry as evidence of particular importance in preliminary investigation pertaining (Ruling of the Chief Administrative Court of May 7,2002) to social support.

Environmental inquiry in the family is conducted by a social worker who in some cases may be accompanied by another social worker or a police officer. The interview is carried out once every 6 months in the case of permanent support, and each time when personal data is altered (Act of March 12, 2004 on social support, art. 107.4). It can be stated that environmental inquiries in families are fundamental tools for social workers which allow them to learn about the family that apply for social support.

The persons and the families benefitting from social support are obliged to cooperate in the improving their difficult life situations. The act on social support notes that failure to agree to participate in an environmental inquiry in the family (or the updating thereof) by individuals or families applying for social support constitutes one of the reasons for the rejection of the application, repealing a decision to grant social support, or placing monetary benefits on hold. The refusal to provide a declaration of income and financial situation shall have the same result (Act of March 12, 2004 on social support, art. 107.4a and 107.5). The decisions pertaining to the benefits of social support are issued in writing. Each decision can be legally appealed. The discoveries made by a social worker ought to be based on the following documents:

an identity card,

duplicate of the birth certificate of a child or the medical record book of a child,

documents defining the legal status of a foreigner in Poland,

decisions on annuities, pensions, pre-pension payments and benefits, early retirement pensions, compensation benefits for teachers, payments for those in resting state, structural annuities, and social annuities,

decisions of a commission on disability and employment, medical decision on inability to work, inability to function independently, decisions of medical commissions,

decisions on disability or the level of disability,

certifications or declarations of employment remunerations, including information about personal income tax down payments, healthcare and pension and annuity fund dues, sick leave fund dues,

certifications or declarations on the level of remuneration received on the basis of agency agreements, order contracts, membership in farmer's associations, including the information about personal income tax down payments, healthcare and pension and annuity fund dues, sick leave fund dues,

certifications or declarations on the duration of employment, including the periods when social security dues were, or were not, paid,

certifications of the reception of annuities, pensions, pre-pension payments and benefits, early retirement pensions, compensation benefits for teachers, payments for those in resting state, structural annuities, and social annuities,

certifications of the borough office or declarations on the area of a farm in hectares,

certifications or declarations on the continuation of education in gymnasium, post-gymnasium schools, secondary schools, or college or university,

decision of a starost on recognition (or the lack thereof) as an unemployed person, the loss of the status of an unemployed person, the denial to grant the status, placement on hold, or the resumption, the loss or the deprivation of the right to unemployment benefits, training benefits, stipend, activation benefits, or the declaration of being registered as an unemployed person or a person seeking employment,

decision of the Social Security Institution on the definition of seed money,

certifications or declarations on obligation to pay social security dues for farmers,

confirmations of the paid social security dues for farmers, 
confirmations of the payment of social security dues by entrepreneurs,

certifications or declarations on the declared basis of the social security dues for entrepreneurs,

certifications of income of entrepreneurs,

certifications or declarations of one-time social support benefits,

decisions of administration bodies granting benefits,

declarations of financial situation (Act of March 12, 2004 on social support, art. 107.4a and 107.5b),

other documents, if required (Act of March 12, 2004 on social support, art. 107.4a and107.5d).

Environmental inquiries in the family are documented by filling in an official form defined in the Ordinance of the Minister of Family, Labour, and Social Policy of August 25, 2016 on environmental inquiries in the family (Ministry of Family, Labour and Social Policy, 2016b). The same legal act defines the method and the times of the conducting of the inquiries, as well as the specimens of declarations of financial situation and the identification cards of social workers.

According to the aforementioned ordinance an environmental inquiry is conducted within 14 days of the reception of the information of the necessity to conduct an inquiry. In urgent cases requiring immediate intervention of a social worker from a social support centre or the poviate centre of support for families the inquiry is to be carried out immediately but not later than 2 days after the reception of the information about the necessity to grant social support benefits. A social worker ought to conduct the inquiry with the individual or the family in their place of registered residence or current residence, on business days, during the working hours of the social support centre or the poviate centre of support for families, or at another date as agreed upon with the individual or the family, with the permission of the head of the particular social support centre. The social worker ought to present their identity card before conducting the inquiry. The template of the identity card is provided in Attachment 4 to the Ordinance of the Minister of Family, Labour, and Social Policy of August 25, 2016 on environmental inquiries in the family (Ministry of Family, Labour and Social Policy, 2016b, § 14 in connection with Attachment 4 to the Ordinance). While the inquiry is being carried out what needs to be taken into account are individual traits, as well as personal, family, financial, and income situation of the person in the single household or the persons in the family, which can all have bearing on the type and the scope of the granted support. As part of the inquiry the social worker analyses and evaluates the situation of the particular individual or the family and formulates conclusions that are the basis for the planned support (Ministry of Family, Labour and Social Policy, 2016b, § 2). Each time the social worker is obliged to inform the individual or the family of the necessity to declare all changes in their personal and financial situation as well as income, which are all connected with the basis to provide support (Ministry of Family, Labour and Social Policy, 2016b, in connection with Act of March 12, 2004 on social support, art. 109).

In some cases an environmental inquiry in the family must be conducted with a legally incapacitated person. In such a situation the inquiry is de facto carried out with their legal guardian or curator, in the presence of the incapacitated person and in their place of residence (Ministry of Family, Labour and Social Policy, 2016b, $\S 5$ ). Sometimes it is necessary to conduct an environmental inquiry in the family in more than one borough. This pertains in particular to the situations when a member of a family is in a hospital, or in a home in a different location, or because the members of the family are separated for other reasons. In such cases it is acceptable to use the help of social workers in the boroughs where the person that is to be interviewed resides (Ministry of Family, Labour and Social Policy, 2016b, in connection with Act of March 12, 2004 on social support, art. 103). The questionnaire of an environmental inquiry in the family can be filled in on paper or electronically. The template of the environmental inquiry in the family form is found in Attachment 1 to the discussed ordinance (Ministry of Family, Labour and Social Policy, 2016b, Attachment 1). It consists of 9 parts:

Part I. Pertains to the persons applying for social support. It includes the personal information of the person with whom inquiry was carried out, information about the family, description of their place of residence of the individual or the family, description of their health and professional situation, as well as the needs and the expectations of the person of the family that were mentioned during the interview. A further element is the evaluation of the situation of the individual or the family and the conclusions of the social worker, a plan of the support for the person or the family, as well as help plan confirmed by the head of a social support centre. 
Part II. Pertains to the spouse, the descendants, and the parents not present in the place of residence of the individual applying for the support. It includes the personal information of the interviewed individual, information about their family members and other cohabitants, description of the help of the individual or the family granted to the individual or the family applying for the support, as well as the persons that can also help the individual or the family applying for support, and conclusions of the social worker.

Part III. It is the update of the information about the spouse, the descendants, and the parents not present in the place of residence of the individual applying for the support. It includes the personal information of the interviewed person and the conclusions of the social worker.

Part IV. Pertains to the persons and the families benefitting from social support and it is an update of the inquiry. It includes the personal information of the person with whom inquiry was carried out, and a description the needs and the expectations of the person or the family that were mentioned during the interview, a plan of the support for the person or the family, as well as help plan confirmed by the head of a social support centre.

Part V. Pertains to persons applying for monetary benefits to become independent or to continue education. It includes personal information of the interviewee, conclusions of the social worker, and information about the decision to grant support.

Part VI. Pertains to the foreigners who have received asylum in Poland. In includes personal information of the interviewee, information about their family members residing in Poland, evaluation of their Polish language skills, description of the functioning of the foreigner and their family members in the new environment after leaving the refugee centre, description of the their residential, health, and professional situation, income, as well as the needs and expectations addressed during the inquiry, the evaluation and the conclusions of the social worker, and a plan of the support for the person or the family, as well as help plan confirmed by the head of a social support centre.

Part VII. Pertains to the persons afflicted by mass crises, as well as natural disasters and accidents. It includes: personal information of the interviewee, description of the losses suffered as the result of the mass-scale crisis, as well as a natural disaster or an accident, as well as the needs and expectations addressed during the inquiry, the evaluation and the conclusions of the social worker, and a plan of the support for the person or the family, as well as the decision of the head of a social support centre.

Part VIII. Pertains to inquiries carried out to define the right to special attendance benefit ${ }^{1}$. It includes: personal information of the subject to inquiry, information gathered by the social worker, as well as conclusions of the social worker conducting the interview.

Part IX. Pertains to the inquiry on how the funds from the upbringing benefit (commonly named " $500+$ " in Poland) are spent 2 . It includes: personal information of the interviewee, information gathered by the social worker in order to verify the doubts as to how care is taken and how the benefit funds are spent, and conclusions of the social worker conducting the inquiry.

A social worker is obliged to fill in the proper part of the form of the environment inquiry in the family depending on the situation defined in the application submitted by the person to receive the benefits or by proper authorities.

As it has been mentioned above, the questionnaire of the environment inquiry in the family is filled in on paper or electronically in the system that is made available free of charge by the minister proper to problems of social security. The system makes sure that, after the environmental inquiry in the family is confirmed, the information received from the person with whom the environmental inquiry in the family was conducted does not change and that it is integral. In the case when

\footnotetext{
${ }^{1}$ This inquiry is defined in art. 23 of the Act of November 28, 2003 on family benefits (Journal of Laws 2003.228.2255 with subsequent amendments).

${ }^{2}$ This inquiry is defined in art. 23 of the Act of November 28, 2003 on family benefits (Journal of Laws 2003.228 .2255 with subsequent amendments) or in art. $15 \mathrm{sec} .1$ or 2 of the Act of February 11, 2016 on government help in upbringing of children (Journal of Laws 2016.00.195 with subsequent amendments). Art. $15 \mathrm{sec}$. 1 states that "If in relation to an individual applying for the upbringing benefit or a person receiving the benefit doubts arise pertaining to their care of their child, (...) the benefit being spent wrongly or of the upbringing benefit being wasted, the proper government body or the voivodship marshal may ask the head of a social support centre to conduct an environmental inquiry in the family". The aforementioned upbringing benefit is the controversial $500+$, that is, the amount of 500 PLN granted to every second child and further children, or to all children in low-income families.
} 
the questionnaire of the environmental inquiry in the family is filled in electronically, after the provided information is confirmed by the social worker, the person with whom the interview was carried out signs a declaration in which they confirm that they have become familiar with the content of the inquiry, the truthfulness of the information provided in the inquiry and having become familiar with the information about the criminal liability for bearing false testimony. The social worker conducting the inquiry types in the signature generated automatically by the system. After the submission the contents of the inquiry cannot be altered (Act of March 12, 2004 on social support, art. 107.4a and $107 \mathrm{sec} .5 \mathrm{e}, 5 \mathrm{f}$, 5f, 5h).

\section{Final conclusions}

The European Social Charter signed by Poland on November 26, 1991 states that in order to secure the proper execution of the right to social support and medical care that state shall provide institutional support to every person incapable of securing them with their own means or the means that they can receive access to. The charter ensures that the persons receiving social support shall not suffer because of limitations of their social and/or political rights, and that each individual can receive from the proper public or private services personal help that is required for their security, and the removal or improvement of personal or family situation. The state secures the use of the aforementioned statements in an equal way to its citizens as well as the citizens of other countries legally residing in Poland (The European Social Charter, art. 13).

The essence of social support are the actions aimed to return and secure independent functioning where it is possible, and where it is not, support and care that guarantee existence with dignity (Starega-Piasek, 1998, p. 9). The goals in the realm of social support ought to be pursued by qualified social services, grouped in social support centres connected with the local administration. All other subjects of social support can and need only to serve a supplementary role. The number of the tasks for the social services makes it necessary for them to be conducted by properly trained personnel provided with proper tools to work with (Ratyński, 2003, pp. 258-259). It is all the more important because we can observe a constant transformation of the system of social support - from institutions of social aid to subjects conducting active social policies (Grewiński, \& Zasada-Chorab, 2012, p. 13). The currently introduced changes are heading towards active social policies, they are aimed to activate the long-term unemployed, those threatened with social exclusion, to make it easier for them to move from the role of a passive client to an active participant in the process of helping and activization of local communities (Grewiński, \& Zasada-Chorab, 2012, p. 13). In the reference sources, however, it is often claimed that a depreciation of the importance of social work in social support has taken place, that it is now a supplementary service to the granting and distribution of benefits. What is symptomatic of this phenomenon is the use of the environmental inquiry in the family by the social workers not as a tool of social diagnosis, but as a "buffer" for administrative decisions to grant benefits (Rymsza, 2011, p. 35). It is not easy to adjucate in this matter, however, the conducted research suggests that there are indeed cases when conducting an environmental inquiry in the family is limited to thoroughly filling out the questionnaire defined by regulations and people and their actual needs are treated with indifference, not as a problem that needs to be solved, but as the object of tedious paperwork (Jurczyk-Romanowska, 2014, pp. 297-315).

\section{References}

[1] Act of February 11, 2016 on government help in upbringing of children. Journal of Laws 2016.00.195 with subsequent amendments.

[2] Act of March 12, 2004 on social support. Journal of Laws 2004.64 .593 with subsequent amendments.

[3] Act of November 28, 2003 on family benefits. Journal of Laws 2003.228.2255 with subsequent amendments.

[4] Broda-Wysocki, P. (n.d.). Pomoc społeczna w Polsce - koncepcja i instrumenty: Ekspertyza przygotowana w ramach projektu „EAPN Polska - profesjonalny dialog na rzecz Europy Socjalnej”. Retrieved December 22, 2016 from http://www.eapn.org.pl/expert/files/Pomoc_spoleczna_w_Polsce_-_dr_P.B-W.pdf.

[5] Grewiński, M., \& Zasada-Chorab, A. (2012). System pomocy społecznej w Polsce - wyzwania i kierunki [System of social support in Poland - Challenges and directions]. Toruń: Regionalny Ośrodek Polityki Społecznej w Toruniu.

[6] Jurczyk-Romanowska, E. (2014). Samotny rodzic w obliczu instytucji - pomiędzy subiektywną opinią a empatia pracowników socjalnych przeprowadzających rodzinny wywiad środowiskowy [Single parents dealing with institutions - the subjective opinion and empathy of social workers conducting community interviews]. Wychowanie w Rodzinie X (2/2014). 297-315. 
[7] Ministry of Family, Labour and Social Policy (2016a). Minister. Retrieved from http://www.mpips.gov.pl/en/about-the-ministry/minister/.

[8] Ministry of Family, Labour and Social Policy (2016b). Ordinance of the Minister of Family, Labour, and Social Policy of August 25, 2016 on environmental inquiries in the family. Journal of Laws 2016.00.1406.

[9] The European Social Charter. Journal of Laws 1993.61.285.

[10] Ministry of Family, Labour and Social Policy (2017). Zasady pomocy społecznej [The principles of social support]. Retrieved from https://www.mpips.gov.pl/pomoc-spoleczna/system-pomocy-spolecznej-wpolsce/zasady-pomocy-spolecznej/.

[11] Ratyński, W. (2003). Problemy i dylematy polityki społecznej w Polsce [Problems and dilemmas of social policy in Poland], vol. 1. Warsaw: Difin.

[12] Rymsza, M. (2011). Pomoc społeczna i praca socjalna w Polsce: perspektywy i bariery rozwoju [Social support and social work in Poland: perspectives and obstacles to development] (pp. 32-41). In: M. Grewiński, \& J. Krzyszkowski (Eds.). Współczesne tendencje w pomocy społecznej i pracy socjalnej [Contemporary tendencies on social support and social work]. Warsaw: Mazowieckie Centrum Polityki Społecznej.

[13] Ruling of the Chief Administrative Court of May 7, 2002, NSA 3337/01, Lex 81651.

[14] Staręga-Piasek, J. (1998). O roli prawa i wartościach w pomocy społecznej [On the role of the law and values in social support], Polityka Społeczna, 7. 9-11. 